\title{
PERAN PPAT DALAM SISTEM PENDAFTARAN TANAH ADAT DI BALI
}

\author{
I Gede Angga Pratama1
}

${ }^{1}$ Fakultas Hukum Universitas Udayana, E-mail: datsworldwide@gmail.com

\begin{tabular}{l}
\hline Info Artikel \\
\hline Masuk: \\
Diterima : \\
Terbit : \\
Keywords : \\
Land Registration System, \\
PPAT Deed, Certificate, Land \\
Right \\
\\
\\
\\
DOI : \\
Xxxxxxx \\
Kata kunci: \\
Sistem Pendaftaran Tanah \\
Adat, Akta PPAT, Sertifikat, \\
Hak Atas Tanah \\
E-mail: \\
datsworldwide@gmail.com \\
\hline
\end{tabular}

\begin{abstract}
The Complete Systematic Land Acceleration Program was launched by the government to accommodate the land registration system in Indonesia because there are still many lands in Indonesia which have not been certified as mandated by Law Number 5 of 1960 concerning Basic Agrarian Principles (UUPA). This regulation aims to accelerate the process of certifying land that does not yet have a certificate in Indonesia. This study aims to determine the role of PPAT in the registration system of customary land in Bali after the enactment of PTSL due to the existence of conflict between PP No. 24 of 1997 concerning land registration with the concerning Basic Agrarian Principles (UUPA). . This writing uses empirical legal methods. The conclusion that can be drawn from this writing is that land registration in Indonesia must be strengthened by written evidence. Written evidence can be made when the implementation of the transfer of a land right is carried out, so the law is required to make a deed.
\end{abstract}

\begin{tabular}{l}
\hline Abstrak \\
\hline Program Percepatan Pendaftaran Tanah Sistematis \\
Lengkap dicanangkan oleh pemerintah untuk \\
mengakomodir sistem pendafaran tanah di Indonesia \\
dikarenakan masih banyak tanah-tanah di Indonesia yang \\
belum di sertifikatkan seperti yang diamanatkan oleh \\
Undang-Undang Nomor 5 Tahun 1960 tentang Peraturan \\
Dasar Pokok-Pokok Agraria (UUPA). Peraturan ini \\
bertujuan untuk mempercepat proses pensertifikatan \\
tanah-tanah yang belum memiliki sertifikat di Indonesia. \\
Penelitian ini bertujuan untuk mengetahui peranan PPAT \\
dalam sistem pendaftaran tanah adat di Bali setelah \\
berlakunya PTSL dikarenanakan adanya adanya \\
pertentangan antara PP Nomor 24 Tahun 1997 tentang \\
pendaftaran tanah dengan UUPA. Penulisan ini \\
menggunakan metode hukum empiris. Hasil penulisan ini
\end{tabular}


menunjukan Pendaftaran tanah di Indonesia harus dikuatkan dengan alat bukti secara tertulis. Alat bukti secara tertulis dapat dibuat ketika pelaksanaan peralihan suatu hak atas tanah dilaksanakan, maka diwajibkan hukumnya agar membuat akta.

\section{Pendahuluan}

Saat bulan Februari 2018, Presiden Joko Widodo menyerahkan langsung 845 (delapan ratus empat pufuh lima) sertipikat hak atas tanah adat untuk pura seProvinsi Bali.2 Penyerahan sertipikat tersebut dilaksanakan di Pura Dalem Sakenan Serangan, Kota Denpasar. Ini merupakan output dari dari program Pendafaran Tanah Sistematis Lengkap (PTSL) yang mulai dicanangkan pada Tahun 2016 yang lalu. PTSL dilaksanakan berdasarkan Permen ATR/Kepala BPN Nomor 35 Tahun 2016 yang mengatur mengenai Percepatan Pendaftaran Tanah Sistematis Lengkap. ${ }^{3}$ Pendafaran tanah sendiri diamanatkan oleh Undang-Undang Nomor 5 Tahun 1960 tentang Peraturan. ${ }^{4}$ Dasar Pokok-Pokok Agraria (UUPA), yang dalam Pasal 19 ayat (1) tersebut menegaskan jaminan kepastian akan hukum diberikan oleh Negara akan diadakan pendaftaran tanah di seluruh wilayah negara Indonesia. Pada ayat (2) tersebut diatur bahwa pendaftaran meliputi :

a. mengukur, memetakan dan membukukan tanah;

b. hak tanah didaftarkan dan dialihkan hak-hak tersebut;

c. diberikanya tanda bukti hak berupa surat/sertifikat, yang diberlakukan sebagai alat bukti.

Berdasarkan ketentuan Pasal 19 tersebut diatas, sebagai pelaksanaanya pada tahun 1961 diterbitkanlah Peraturan mengenai Pendaftaran Hak Atas Tanah dalam PP Nomor 10 Tahun 1961, yang pada Tahun 1997 telah diganti dengan terbitnya PP Nomar 24 Tahun 1997 tentang Pendaftaran Tanah. Surat tanda bukti hak yang dimaksud dalam ketentuan tersebut adalah sertipikat. Sertipikat adalah bukti kepemilikan tanah berupa surat sebagaimana dimaksud dalam Pasal 19 ayat (2) huruf c UUPA untuk hak-hak atas tanah pengelolaan, tanah hak waris, dan tanah hak milik atas sarusun dan Hak Tanggungan yang semuanya sudah terdaftar pada buku tanah yang bersangkutan.

\footnotetext{
2 Ni Putu Eka Wiratami, "Jokowi Serahkan Sertifikat Tanah Adat Ke Masyarakat Bali", Available from http;//m-bisnis-com.cdn.ampproject.org,diakses 24 Januari 2019, jam 11.30 Wita

${ }^{4}$ Putri, C. A \& Gunarto, G, (2018). Efektivitas Pengecekan Sertifikat Terhadap Pencegahan Sengketa Dalam Proses Peralihan Hak Atas Tanah, Jurnal Akta, 5(1), 265-274, hal. 269
} 
PPAT merupakan pejabat yang diberikan wewenang dalam hal pembutan aktaakta otentik terhadap beberapa perbuatan hukum yang mengatur tentang hak tanah atau Hak Milik. ${ }^{5}$ PP Nomor 37 Tahun 1998 tentang Peraturan Jabatan Pejabat Pembuat Akta Tanah ini mengatur tentang tugas-tugas utama dan kewenangan PPAT, yang di dalamnya diatur pula syarat pengangkatan sebagai PPAT. Dalam Peraturan ini disebutkan bahwa PPAT memiliki kewenangan untuk membuat akta peralihan hak berupa jual beli, tukar menukar, penghibahan, APHB, pemberian Hak Guna Bangunan, Hak Pakai atas Tanah Hak Milik, pemberian Hak Tanggungan, dan hak memberikan Kuasa membebankan Hak Tanggungan (Pasal 2 ayat (2) PP Nomor 37 Tahun 1998).

Dari ketentuan tersebut terlihat bahwa setiap penting dilakukannya penelitian mengenai Peran PPAT Dalam Sistem Pendaftaran Tanah Adat di Bali, dengan rumusan masalah yaitu Bagaimanakah prosedur pendaftaran hak atas tanah di Bali setelah adanya program Pendafaran Tanah Sistematis Lengkap (PTSL) ? dan Bagaimanakah peran PPAT di dalamnya?.

Secara umum, penelitian ini bertujuan untuk memberikan sumbangan keilmuan dalam pengembangan ilmu hukum, khususnya yang berkaitan dengan prosedur pendaftaran hak atas tanah. Secara khusus, sesuai dengan rumusan masalah tujuan penulisan ini yaitu untuk mengetahui prosedur pendaftaran hak atas tanah di Bali setelah adanya program Pendafaran Tanah Sistematis Lengkap (PTSL) serta peran PPAT dalam sistem pendaftaran tanah adat di Bali.

\section{Metode Penelitian}

Penelitian ini merupakan penelitian hukum empiris. Data primer diperoleh dari hasil penelitian lapangan pada Badan Pertanahan Nasional Propinsi Bali. Data sekunder melalui bahan kepustakaan, arsip ilmiah, dokumen ilmiah yang terdiri dari bahan hukum primer yaitu UUPA, PP Nomor 10 Tahun 1961, Permen ATR/BPN Nomor 3 Tahun 1997, Permen ATR/BPN Nomor 35 Tahun 2016 mengenai PTSL, dan bahan sekunder menggunakan karya ilmiah, dan dokumen hukum. ${ }^{6}$ Metode pengumpulan data primer dilakukan dengan cara wawancara/interview secara langsung, mengajukan beberpa pertanyaan yang relevan terhadap pejabat yang berwenang di BPN. Data yang terkumpul tersebut dianalisa dengan metode analisis deskriptif untuk memperoleh hasil akhir. ${ }^{7}$

\footnotetext{
${ }^{5}$ Ibid

6 Soerjono Soekanto. (2012). Pengantar Penelitian Hukum. Jakarta, UI Press. hal. 11.

${ }^{7}$ Ibid, hal. 22.
} 


\section{Hasil Dan Pembahasan}

\subsection{Sistem pendaftaran hak atas tanah di Bali setelah adanya program Pendafaran Tanah Sistematis Lengkap (PTSL)}

Pengertian proses pensertipikatan dalam penelitian ini dibagi atas 2 denifisi, yakni, dapat menjadikan kepemilikan suatu hak tanah ketika belum mempunyai sertipikat menjadi mempunyai sertipikat atas nama pemilik yang sama dan menjadikan kepemilikan suatu tanah yang disertipikati berubah menjadi nama orang/pihak yang menerima peralihan/pengalihan kepemilikan tanah tersebut.

Dasar hukum dalam persertipikatan kepemilikan tanah dan mengatur persertipikatan kepemilikan tanah diatur dalam ketentuan PP mengeni pendaftaran tanah yang diatur dalam PP Nomor 24 Tahun 1997. Dalam PP tersebut pada intinya mengatur mengenai tata cara awal melakukan pendaftaran tanah serta menjaga segala bentuk data yang digunakan ketika melakukan pendaftaran tanah. Selanjutnya, untuk proses pensertipikatan telah diatur di butir a di atas dikenal juga dengan istilah "konversi" pada Pasal 11 tersebut termasuk inti dari isi PP pembahasan di atas.

Secara historis, sistem pendaftaran tanah dapat mengacu pada Ordonansi Balik Nama (selanjutnya disebut OBN) yang berlaku pada era 1843. Di dalam OBN untuk melakukan suatu peralihan hak diharuskan untuk membuat akta. Akta tersebut hanya dapat dibuat oleh pejabat pendaftar tanah pada masa itu dan dinamakan akta van overschrijving. Didalam akta tersebut, telah memuat pointpoint dari kepemilikan tanah yang akan dialihkan tanda bahwa telah terjadinya suatu penerbitan suatu hak yang terkandung di dalam akta tersebut. ${ }^{8}$

Berdasarkan OBN pada masa itu, masyarakat sejatinya telah diberikan kemudahan untuk melakukan perbuatan hukum pendaftaran tanah. Adanya akta van overschrijving dapat memberikan suatu kepastian hukum terhadap perbuatan peralihan tersebut, karena akta tersebut dapat dikatakan sebagai bentuk bukti bahwa telah adanya suatu pendaftaran hak atas tanah (bewijs van elgendom). Hal tersebut sejalan dengan KUH Perdata, karena di dalam Pasal 1459 pada intinya membahas mengenai tata cara peralihan suatu benda yang akan dibeli secara sah. Dalam proses pendaftaran tanah pada umumnya yang telah terjadi di Indonesia, melakukan suatu pendaftaran hak atas tanah, sejarah kepemilikan tanah yang telah berpindah tersebut dapat dilihat dari data riwayat kepemilikan tanah dari awal hingga ke pemilik akhir tanah terebut. Dengan adanya pengecekan data kepemilikan tanah tersebut, maka akan dapat

\footnotetext{
8 Budiono, Herlien.(2007). Kumpulan Tulisan Hukum Perdata di Bidang Kenotariatan, Bandung, PT Citra Aditya Bakti. hal .17
} 
membantu proses pembukuan dengan baik, melihat secara jelas batas tanah tersebut dan memberikan titik terang dalam memperjelas dan memberikan perlindungan hukum bagi siapapun yang sah untuk kepemilikan atas tanah tersebut.

Apabila berpedoman kepada PP Nomor 24 Tahun 1997 tentang Pendaftaran Tanah yang telah disebutkan diatas, pembukuan atas kepemilikan tanah akan dicatatkan atas nama orang yang mengajukan pendaftaran tersebut dan dicatat dalam buku pertanahan namun akan berdampak negatif terhadap orang yang mempunyai hak atas tanah tersebut akan menjadi hilang haknya untuk memiliki tanah itu. Akan tetapi, orang yang berhak tersebut tidaklah serta merta akan hilang haknya, karena hak tersebut masih bisa diperoleh dengan cara melakukan gugatan guna memunculkan haknya di dalam buku pertanahan. Sedangkan, apabila mengacu kepada UUPA, dalam pendaftaran tanah dapat berupa pengalihan hak.

Mengingat adanya perbedaan diantara PP Nomor 24 Tahun 1997 dan UUPA di mana kedua aturan tersebut sama-sama mengatur mengenai pendaftaran tanah maka dapat ditarik pengertian yang sama jika pendaftaran tanah di Indonesia harus dikuatkan dengan alat bukti secara tertulis. Alat bukti secara tertulis dapat dibuat ketika pelaksanaan peralihan suatu hak atas tanah dilaksanakan, maka diwajibkan hukumnya agar membuat akta. Di dalam akta yang terlibat wajib untuk membubuhkan tanda tangannya guna menjamin kekuatan pembuktian dari pemilik atas tanah yang selanjutnya. Apabila terdapat bukti yang kuat, maka akan meminimalisir atau mengurangi terjadinya permasalahan di kemudian hari.

Surat yang memuat tentang keterangan yang berisikan kebenaran suatu hal yang dibuat oleh pejabat berwenang secara resmi disebut dengan sertifikat. ${ }^{9}$ Sedangkan pemahaman mengenai sertifikat tanah dapat dikatakan sebagai alat bukti atas suatu bidang tanah yang berupa surat. ${ }^{10}$ Adapun contoh dari bentuk suatu sertifikat tanah dapat berupa surat ukur dan buku tanah. Bentuk-bentuk tersebut memiliki kegunaan yang berbeda-beda. Di dalam surat ukur menjelaskan mengenai batas-batas tanah, letak, bentuk tanah, luas gambar, serta penguraian lainnya mengenai obyek tanah tersebut. Adapun buku tanah berisikan hal-hal yang berhubungan dengan riwayat kepemilikan hak atas tanah tersebut yang berupa pemegang hak, data terhadap subyek dan obyek hak dan luas tanah tersebut.

\footnotetext{
9 Santoso, Urip (2010). Sikap Pendaftaran dan Peralihan Hak Atas Tanah. Jakarta. Kencana Pranada Media Group. hal. 25.

${ }^{10} \mathrm{Ibid}$
} 
Mengenai pelaksanaan suatu pendaftaran tanah terdapat dua cara yaitu dengan metode sporadik dan metode sistematis. ${ }^{11}$ Pada umumnya, dikatakan sebagai metode sistematis dikarenakan pendataan mengenai seluruh obyek tanah yang belum di daftarkan di suatu daerah tertentu, sehingga metode sistematis digunakan dalam mendaftarkan tanah untuk pertama kalinya agar seseuai dengan sistem berdasarkan susunan rencana kerja yang telah ada di setiap wilayah. ${ }^{12}$ Dalam perkembangannya, terhadap tanah yang ingin di daftarkan secara sistematis dapat dilakukan percepatan pelaksanaan prosesnya. Dengan percepatan ini, proses pengumuman segala bentuk data yang telah dikumpulkan dari kepemilikan tanah tersebut yang akan disertipikatkan dipercepat terhitung semula 30 hari menjadi hanya 14 hari. Obyek yang sudah lengkap dalam melakukan pendaftaran ini meliputi semua bagian dari obyek tanah tersebut. keseluruhan tanah tersebut berupa segala bentuk aset tanah milik Negara seperti hutan, tanah adat, tanah milik daerah. Sedangkan metode sporadik dimaksud pendaftaran tanah yang dilakukan secara pribadi ataupun beberapa orang yang dilakukan di suatu tempat/wilayah dengan maksud untuk mendaftarkan tanah atas suatu kepentingan.

Proses pertama yang harus dilakukan dalam mendaftarkan obyek tanah diawali dengan melakukan pencarian data dan menemukan data-data dengan melakukan pemetaan dan pengukuran, selanjutnya akan ditetapkan batas wilayah dan dibuatkan dasar pendaftaran tanah berupa peta, pembuktian hak serta pembukuannya, dan diakhiri dengan penerbitan sertipikatnya. Untuk pembuktian kepemilikan yang baru, ketika proses dilangsungkan sangat dibutuhkan pembuktian dengan akta PPAT. Di dalam akta tersebut, akan menjelaskan secara jelas mengenai kepemilikan hak tersebut yang telah memiliki wewenang mengenai segala bentuk penggunaan hak, baik itu berupa hak pakai, HGB, dll.

Apabila suatu saat nanti telah terjadi suatu perubahan-perubahan baik secara fisik maupun yuridis, maka akan dilakukan pemeliharaan data dalam tanah yang telah didaftarkan. Dengan demikian, apabila terjadi perubahan tersebut, pemilik tanah wajib untuk memberikan segala informasi tersebut ke kantor pertanahan. Proses ini diawali dengan dibuatkannya akta yang mencakup mengenai hak yang akan dipindahkan dan pembebanan terhadap pemilik yang dilakukan dihadapan PPAT, kemudian dengan tenggang waktu 7 (tujuh) hari sejak akta ditandatangani, akta PPAT beserta dokumen pendukungnya disampaikan kepada Kantor Pertanahan. Pemindahan kepemilikan tanah dapat pula terjadi karena pelelangan ataupun suatu peleburan, adanya proses turun waris, dll. Bentuk dari penyelenggaraan suatu pendaftaran tanah akan dibuatkan daftar umum yang berisikan kumpulan kegiatan inventarisir

\footnotetext{
${ }^{11}$ Andriyani, K., \& Surata, I, G, (2019), Pendaftaran Tanah Secara Recht Kadaster Melalui Proses Konversi, Kertha Widya, 4(2). hal. 92

${ }^{12}$ Ibid
} 
pendaftaran tanah desa demi desa meliputi daftar tanah, daftar buku tanah dan lain lain.

Tanah yang belum dapat di daftarkan di kantor Badan Pertanahan Nasional, untuk dapat membuktikan suatu perkara-perkara pengadilan dapat dilakukan pembuktian dengan cara menunjukan bukti hak dengan berupa surat-surat penguat, akta di bawah tangan ataupun alat bukti lainnya yang menjadi penguat dalam kepemilikan tanah adat. Pensertifikatan merupakan proses akhir dari:

a. Tahap menyelidiki baik itu berupa riwayat peralihan yang hasilnya nanti merupakan pemegang hak pertama.

b. Tahapan pengalihan hak untuk berikutnya, dengan akta PPAT.

Pemegang hak atas tanah terakhir akan didapatkan dalam lembaga kadaluwarsa dengan jangka waktu yang telah ditentukan oleh pemegang hak melalui akta PPAT, yang dikuatkan dengan pendapat dari Gede Irwan Agustian, S.ST,MH., selaku Kepala Subseksi Pendaftaran Hak Atas Tanah Badan Pertanahan Kota Denpasar pada intinya menyampaikan "sebelum akta di daftarkan, akta tersebut harus diperiksa terlebih dahulu untuk melihat kecocokannya terhadap akta terdahulu yang telah terdaftar. ${ }^{13}$ Adapun sistem pertanahan di Indonesia menganut sistem pendaftaran negatif, sehingga seluruh akta harus dikaitkan ke persil yang berhubungan. Oleh karena itu, dengan melihat kecocokan terhadap akta terdahulu secara tidak langsung akan menjamin pendaftaran tersebut tervalidasi dengan sah"

\subsection{Peranan PPAT Dalam Sistem pendaftaran hak atas tanah adat di Bali.}

Pada masa lampau apabila kita kaitkan pada sistem hingga saat ini, point terpenting dari suatu peralihan tanah tersebut berupa akta yang mengatas namakan pemilik baru, yang sebelumnya merupakan pergantian dari pemilik tanah yang lama. Dengan bergantinya silsilah kepemilikan tanah tersebut dengan yang baru, maka secara hukum telah menjamin bahwa pemilik tanah yang baru kuat dengan akta tersebut. ${ }^{14}$ Namun, tidak menutup kemungkinan di kemudian hari apabila terjadi sengketa, akta tersebut dapat digugat oleh siapapun. Semasih ada pihak yang memiliki alat bukti ataupun membuktikan kebenarannya dengan mutlak, maka akta tersebut masih dapat dilakukan klaim kepemilikan melalui gugatan baik perdata maupun pidana.

\footnotetext{
${ }^{13}$ Wawancara dengan Gede Irwan Agustian, S.ST,MH., tanggal 28 Januari 2019 di kantor Badan Pertanahan Kota Denpasar

${ }^{14}$ Arifuddin, Widhiyanti, H. N., \& Susilo, H. (2017). Implikasi Yuridis Terhadap Pejabat Pembuat Akta Tanah Penerima Kuasa Menyetor Uang Pajak Penghasilan/Bea Perolehan Hak Atas Tanah Dan Bangunan Dari Wajib Pajak. Jurnal Ilmiah Pendidikan Pancasila dan Kewarganegaraan Fakultas Hukum Universitas Brawijaya, I, 102-119, hal. 19
} 
Bentuk dari berlakunya sistem negatif di Indonesia adalah dengan diaturnya tata cara pendaftaran tanah oleh Pemerintah. Klasifikasikan pendaftaran tanah menjadi 2 pemahaman yaitu pendaftaran yang dianggap sebagai bentuk peralihan hak yang akan dijamin oleh hukum adalah peralihan tersebut dianggap telah sah secara hukum dan yang kedua adalah penerbitan atas didasari oleh akta PPAT. ${ }^{15}$ Sehingga dengan kata lain, ketika suatu saat nanti terdapat beberapa kesalahan yang menimbulkan cacat hukum pada akta PPAT dikaitkan dengan kekuatan pembuktian, baik itu pembuktian formal, materil dan pihak ketiga dapat menyebabkan ketidakpastian hukum karena kekuatan dari pembuktian akta tersebut harus dibuktikan kembali dengan bukti-bukti yang telah disiapkan oleh para pihak-pihak yang merasa layak untuk memliki tanah tersebut.

Menurut ketentuan dalam kelembagaan "kedaluwarsa", telah memberikan jaminan secara hukum bahwa siapapun yang telah didaftarkan untuk pertama kalinya adalah orang yang sah menurut hukum dan memiliki rentan waktu tertentu. Disisi lain, akta yang telah dibuat juga mengikat secara sempurna yang menjamin peralihan hak untuk selanjutnya. Sehingga, apabila di sinkronisasikan dengan aturan-aturan lain, maka pada hakekatnya proses pendaftaran tanah yang telah dilakukan sesuai prosedur dan tahapan memiliki kekuatan hukum yang sempurna.

Oleh karena itu, untuk meminimalisir hal-hal yang buruk, pemberlakuan terhadap PP Nomor 10 tahun 1961 menjadi lebih ditingkatkan secara berjenjang. Peningkatan tersebut dipusatkan kepada PPAT dengan syarat setiap pejabat diwajibkan untuk mengikuti ujian yang telah di adakan oleh Pemerintah maupun pejabat Agraria. hal tersebut bertujuan agar PPAT lebih kompeten dalam membuat akta peralihan atas tanah. Disisi lain, karena kurangnya pemerataan penempatan PPAT, perangkat desa yaitu camat dapat di angkat dan dijadikan PPAT untuk sementara. Dengan kata lain, keberadaan camat juga menjadi penopang penting untuk pelaksanaan suatu peralihan hak atas tanah. Sehingga Camat juga akan mendapatkan pelatihan yang sama seperti layaknya PPAT yang resmi. Pemerintah juga telah memberikan perlindungan hukum terhadap PPAT maupun Camat dikarenakan jika suatu saat nanti telah terjadi permasalahan hukum yang menjurus ke dalam akta PPAT maka kepemilikan atas nama pemilik tanah di sertifikat tersebut dapat dibatalkan melalui surat keputusan Mendagri.

Untuk keperluan pendaftaran hak dalam rangka penerbitan sertipikat, Segala bentuk pembuktiannya dapat diajukan ke kepala kantor pertanahan atau panitia ajudikasi. Pembuktian tersebut dapat berupa data-data tertulis yang

\footnotetext{
${ }^{15}$ Arifin, Z \& Muhlashon, M. I. (2019). Perlindungan Hukum Pemegang Sertifikat Hak Atas Tanah Sebagai Bukti Kepemilikan Tanah, MIZAN, Jurnal Ilmu Hukum,8(1), 45-54. hal. 29
} 
telah disiapkan oleh pihak yang meminta pengajuan tersebut. Selain itu, keterangan pernyataan dari saksi juga dapat menjadi alat bukti dalam pengajuan pendaftaran dan nantinya akan dilakukan penilaian dan pertimbangan oleh kepala kantor pertanahan. ${ }^{16}$ Penilaian tersebut berdasarkan ketentuan PP Nomor.24 Tahun 1997 dalam.Pasal 24 yang pada intinya membahas mengenai pendaftaran tanah secara sporadik beserta syarat-syarat yang dibebankan terhadap siapapun yang menerima hak.Begitu juga pengertian terhadap pemilik hak lama yang diatur dalam UUPA pada Pasal 2 membahas tentang konversi, diantaranya tanah druwe dan tanah desa adat yang memiliki hak dan hak-hak atas tanah adat dengan nama apapun juga, sehingga termasuk pula tanah adat, tanah desa ayahan, atanah desa pekarangan maupun laba pura, tanah ayahan desa di Bali. Dengan demikian untuk pensertipikatan tanah-tanah adat di Bali ini prosesnya sama seperti pensertipikatan tanah sesuai penjelasan yang telah dijelaskan diatas.

Dengan berakhirnya seluruh waktu, baik secara sistematik 30 hari dan sporadik 60 hari, maka tahap selanjutnya adalah pengumuman mengenai data-data yang telah didaftarkan dan diumymkan langsung oleh tim ajudikasi dan kantor pertanahan. Proses selanjutnya adalah mengesahkan pendaftaran tanah tersebut dan dimasukan kedalam berita acara yang disiapkan Kementerian ATR/BPN. Sedangkan untuk PTSL pengumumannya 14 (empat belas) hari kerja. Dengan dikeluarkannya berita acara, maka tanah tersebut akan dibukukan di dalam buku pensertifikatan tanah, diberikannya pengakuan atas tanah tersebut disahkannya kepemilikan tanah tersebut.

Dapat dilihat bahwa tidak mutlak diperlukan adanya akta yang dibuat/dikeluarkan oleh PPAT. Akta tersebut dibutuhkan hanya perihal:

a. Untuk pembuktian hak tanah baru, maksudnya hanya memuat mengenai keterangan kepemilikan hak yang lama dialihakan kepada pemilik yang baru yang berisikan segala ketentuan yang berhubungan dengan hak tanah berupa hak untuk memakai, HGB, dll.

b. Untuk perubahan-perubahan yang merupakan bagian dari pemeliharaan data tanh tersebut. Hal itu merupakan perbuatan yang sah menurut hukum. Contohnya adalah hak tanggungan, proses jual beli, penghibahan, dll.

Untuk pendaftaran hak atas tanah adat di Bali, misalnya: untuk tanah laba pura yang belum bersertipikat, pendaftarannya hingga terbitnya sertipikat cukup melalui pendaftaran sistematis lengkap (PTSL), atau bisa juga secara sporadik yang diajukan langsung ke Kantor Pertanahan setempat. Bahkan untuk PTSL tidak perlu mengajukan sendiri, melainkan akan didata secara iangsung oleh Kepala Desa setempat untuk kemudian diteruskan kepada Kantor Pertanahan,

\footnotetext{
${ }^{16}$ Rismayanti, I. A. W, (2016). Tanggung Jawab Pejabat Pembuat Akta Tanah (PPAT) terhadap Pendaftaran Peralihan Hak Atas Tanah yang Menjadi Objek Sengketa. Acta Comitas, I, 77-93, hal. 83
} 
yang akan proaktif "jemput bola" meiakukan pendaftaran hingga terbitnya sertipikat. Untuk pendaftaran secara sistematis maupun secara sporadik ini tidak diperlukan adanya akta PPAT. Akta PPAT baru dibutuhkan manakala dilakukan perbuatan hukum sebagaimana dimaksud dalam Pasal 2 ayat (2) PP Nomor 37 Tahun 1998 tersebut di atas.

\section{Kesimpulan}

Proses pertama yang harus dilakukan dalam mendaftarkan obyek tanah diawali dengan melakukan pencarian data dan menemukan data-data dengan melakukan pemetaan dan pengukuran, selanjutnya akan ditetapkan batas wilayah dan dibuatkan dasar pendaftaran tanah berupa peta, pembuktian hak serta pembukuannya, dan diakhiri dengan penerbitan sertipikatnya. Untuk pembuktian kepemilikan yang baru, ketika proses dilangsungkan sangat dibutuhkan pembuktian dengan akta PPAT. Namun proses pensertipikatan hak tanah adat (termasuk hak atas tanah adat di Bali) melalui PTSL maupun sporadik, tidak ada peranan PPAT didalamnya, sebab tidak diperlukan akta yang dibuat dihadapan/oleh PPAT, kecuali untuk mengesahkan fotokopi dokumen sesuai dengan aslinya untuk fotokopi dokumen pendukung yang diperlukan atau untuk perbuatan hukum berupa pemberian hak guna bangunan atau hak pakai atas tanah hak milik. Terdapat adanya peranan PPAT dalam setiap perbuatan hukum berupa pemindahan hak atau pembebanan hak atas tanah, termasuk hak-hak atas tanah adat di Bali, karena perbuatanperbuatan hukum tersebut harus dibuktikan dengan Akta PPAT untuk keperluan pendaftaran di Kantor Pertanahan guna penerbitan setipikatnya.

\section{Ucapan Terima Kasih (Acknowledgments)}

Terimakasih atas segala anugerah yang Tuhan berikan kepada penulis karena telah memberikan waktu yang cukup untuk menyelesaikan penelitian ini. Penulis berterimakasih atas segala kesempatan dan fasilitas yang telah diberikan oleh Fakultas Hukum Universitas Udayana serta para dosen, staff dan teman-teman yang telah berkontribusi dan memberi semangat dalam penyelesaian penelitian ini.

\section{Daftar Pustaka / Daftar Referensi}

\section{$\underline{\text { Buku }}$}

Budiono, Herlien, (2007). Kumpulan Tulisan Hukum Perdata di Bidang Kenotariatan, Bandung, PT Citra Aditya Bakti.

Soekanto, Soerjono, (2012). Pengantar Penelitian Hukum. Jakarta, UI Press. 
Santoso, Urip, (2010), Pendaftaran dan Peralihan Hak Atas Tanah, Jakarta, Kencana Pranada Media Group.

\section{Jurnal}

Andriyani, K., \& Surata, I, G, (2019), Pendaftaran Tanah Secara Recht Kadaster Melalui Proses Konversi, Kertha Widya, 4(2).

Arifin, Z \& Muhlashon, M. I. (2019). Perlindungan Hukum Pemegang Sertifikat Hak Atas Tanah Sebagai Bukti Kepemilikan Tanah, MIZAN, Jurnal Ilmu Hukum, 8(1), 45-54.

Arifuddin, Widhiyanti, H. N., \& Susilo, H. (2017). Implikasi Yuridis Terhadap Pejabat Pembuat Akta Tanah Penerima Kuasa Menyetor Uang Pajak Penghasilan/Bea Perolehan Hak Atas Tanah Dan Bangunan Dari Wajib Pajak. Jurnal Ilmiah Pendidikan Pancasila dan Kewarganegaraan Fakultas Hukum Universitas Brawijaya, I, 102-119.

Putri, C. A \& Gunarto, G, (2018). Efektivitas Pengecekan Sertifikat Terhadap Pencegahan Sengketa Dalam Proses Peralihan Hak Atas Tanah, Jurnal Akta, 5(1), 265-274.

Rismayanti, I. A. W, (2016). Tanggung Jawab Pejabat Pembuat Akta Tanah (PPAT) terhadap Pendaftaran Peralihan Hak Atas Tanah yang Menjadi Objek Sengketa. Acta Comitas, I, 77-93.

\section{Website}

Ni Putu Eka Wiratami, “Jokowi Serahkan Sertifikat Tanah Adat Ke Masyarakat Bali", Retrived from http;//m-bisnis-com.cdn.ampproject.org, diakses 24 Januari 2019, jam 11.30 Wita

\section{Undang-undang}

Undang-Undang Nomor 5 Tahun 1960 tentang Peraturan Dasar Pokok-pokok Agraria. (Lembaran Negara 1960 Nomor 104 - Tambahan Lembaran Negara Nomor 2043)

Peraturan Pemerintah Nomor 10 Tahun 1961 tentang Pendaftaran Tanah. (Lembaran Negara 1961 Nomor 28 -Tambahan Lembaran Negara Nomor 2171)

Peraturan Pemerintah Nomor 24 Tahun 1997 tentang pendaftaran tanah. (Lembaran Negara 1997 Nomor 59 - Tambahan Lembaran Negara Nomor 3696) 
Peraturan Menteri Negara Agaria / Kepala BPN Nomor 3 Tahun 1997 tentang Ketentuan Pelaksanaan Peraturan Pemerintah Nomor 24 Tahun 1997 tentang Pendaftaran Tanah

Peraturan Menteri Agraria Dan Tata Ruang/Kepala Badan Pertanahan Nasional Nomor 35 Tahun 2016 tentang Percepatan Pendaftaran Tanah Sistematis Lengkap

\section{DATA INFORMAN}

1. Nama : Gede Irwan Agustian, S.ST, MH

NIP : 197809251998031003

Jabatan : Kepala Subseksi Pendaftaran Hak Atas Tanah Badan Pertanahan Kota Denpasar 